\title{
Impact of climate change on potential distribution of xero-epiphytic selaginellas (Selaginella involvens and $S$. repanda) in Southeast Asia
}

\author{
AHMAD DWI SETYAWAN ${ }^{1,2, \boldsymbol{v}}$, JATNA SUPRIATNA ${ }^{1}$, DEDY DARNAEDI ${ }^{3}$, ROKHMATULOH $^{4}$, SUTARNO $^{2}$, \\ SUGIYARTO², ILYAS NURSAMSI ${ }^{5,6}$, WULAN RATNA KOMALA ${ }^{5}$, PRAKASH PRADAN ${ }^{7}$ \\ ${ }^{1}$ Program of Conservation Biology, Department of Biology, Faculty of Mathematics and Natural Sciences, Universitas Indonesia. Depok 16424, West \\ Java, Indonesia \\ ${ }^{2}$ Department of Biology, Faculty of Mathematics and Natural Sciences, Universitas Sebelas Maret. J1. Ir. Sutami 36A Surakarta 57126, Central Java, \\ Indonesia. Tel./fax.: +62-271-663375, `email: volatileoils@gmail.com \\ ${ }^{3}$ Division of Botany, Research Center for Biology, Indonesian Institute of Sciences, Cibinong-Bogor 16911, Indonesia \\ ${ }^{4}$ Department of Geography, Faculty of Mathematics and Natural Sciences, Universitas Indonesia. Depok 16424, West Java, Indonesia \\ ${ }^{5}$ Department of Biology, Faculty of Mathematics and Natural Sciences, Universitas Padjadjaran. Jatinangor, Sumedang 45363, West Java, Indonesia \\ ${ }^{6}$ Bird Conservation Society (BICONS). Bandung 40184, West Java, Indonesia \\ ${ }^{7}$ West Bengal Biodiversity Board, Department of Environment, Government of West Bengal, Salt Lake, Sector-III, FD415A, Poura Bhawan, 4th Floor, \\ Kolkata, West Bengal, India
}

Manuscript received: 13 September 2017. Revision accepted: 27 October 2017.

\begin{abstract}
Setyawan AD, Supriatna J, Darnaedi D, Rokhmatuloh, Sutarno, Sugiyarto, Nursamsi I, Komala WR, Pradan P. 2017. Impact of climate change on potential distribution of xero-epiphytic selaginellas (Selaginella involvens and S. repanda) in Southeast Asia. Biodiversitas 18: 1680-1695. Climate change is one of the greatest challenges for all life on earth, as it may become the dominant driver of changes in ecosystem services and biodiversity loss at the global level. Selaginella is a group of spike-mosses that seem easily affected by global warming (climate change) due to requiring water medium for fertilization. However, some species have been adapted to dry condition and may grow as epiphytes, such as $S$. involvens and $S$. repanda. Both species are commonly found in opposing a range of elevation. S. involvens is often found in high-altitude regions, whereas $S$. repanda is often found at lower-altitude regions. The difference in this altitudinal distributions is expected to limit redistribution mechanism of each species to adapt the climate change projections. This study model examines the potential geographic distribution of $S$. involvens and S. repanda under current climatic conditions and models the impact of projected climate change on their potential distribution. Future climate predictions are made with four detailed bioclimatic scenarios (i.e. RCP 2.6, RCP 4.5, RCP 6.0, and RCP 8.5) and three-time intervals (2030, 2050, 2080), which combine various climatic factors. In this modeling, it can be concluded that $S$. involvens and $S$. repanda can adapt to future climate change, and continue to be sustainable, although it is strongly influenced and shifting habitat distribution in some areas.
\end{abstract}

Keywords: Climate change, Selaginella involvens, Selaginella repanda, Southeast Asia, potential distribution, xerophytic

\section{INTRODUCTION}

Current trend on climate change is recognized to be one of the greatest challenges for all life on earth (Fitzpatrick et al. 2008). Intergovernmental Panel on Climate Change (IPCC) developed scenarios which project a further increase in global mean surface temperature of $2.6-4.8^{\circ} \mathrm{C}$ above pre-industrial levels by the year 2100 , spatial and temporal changes in precipitation patterns, and increased incidence of floods and droughts (IPCC 2014). The negative impact of climate change, if combined with continuous environmentally destructive human activities, will become more intense and frequent. The debate of potential ecological impact of ongoing climate change has intensified over the last decade (e.g. Gilman et al. 2010; Pereira et al. 2010; Salamin et al. 2010; Beaumont et al. 2011; Dawson et al. 2011; McMahon et al. 2011; Alice et al. 2012; Bellard et al. 2012; Belgacem and Louhaichi 2013). It has been forecasted that climate change and its impacts may become the dominant driver of changes in ecosystem services and biodiversity loss at the global level (Deb et al. 2017). In the context of understanding the ecological responses to climate change, it may be more relevant to understand the changes in region which are spatially heterogeneous rather than the approximated global averages (Walther et al. 2003; Bonebrake and Mastrandrea 2010). There are five global climate domains in the world: i.e., tropical, subtropical, temperate, boreal, and polar (FAO 2000, 2012). Among all of these global climate domains, the tropical biome has the highest rate of forest degradation and destruction (Morris 2010; Hansen et al. 2013; Deb et al. 2017). Therefore, it becomes very important to study the biodiversity-climate interaction in highly modified tropical landscapes (Wilson et al. 2016).

One of the most vulnerable areas to the impact of climate change is Southeast Asia (SEA), due to its large and growing population, the economic importance of its agricultural sector, its long coastlines and low-lying areas, and its high dependence on natural resources for development (NIC 2009). The climate of Southeast Asia is monsoonal with summer-dominant rainfall and a largescale seasonal reversal of the wind regimes (Loo et al. 2015). A significant increase of mean temperature, acceleration of annual rainfall, and extreme climate events 
such as drought, floods, and cyclones are several projected negative impacts of climate change in SEA (IPCC 2014; Loo et al. 2015). Frequent changes and shifts in monsoon precipitation up to $70 \%$ below normal level, and the delayed of monsoon by up to 15 days are also projected as the effects of the predicted increase in mean temperature (Schewe and Levermann 2012). Along with unsustainable utilization of natural resources, climate change is believed to negatively affects the current plant diversity patterns. These threats are expected to lead to reduced plants biodiversity, low emergence of annual species, the life cycle of plants, and changes in phenology and the timing of reproduction (Thuiller et al. 2008; Belgacem et al. 2008; Hilbish et al. 2010; Hill and Preston 2015).

Among the biotic components of vegetation, spikemosses are one of the earliest groups to be affected by climate change, through the change in their response to climate, distribution, and phenology. The gametophyte generation of spore-bearing vascular plants such as spikemosses is highly dependent on wet environment (Bellard et al. 2012). Therefore, the disruption of spike-mosses life cycle is also being one of negative effect of climate change. Although plants generally respond slowly to climate change, the short lifespans of spike-mosses will likely make them adapt fast enough to avoid several negative impacts of climate change, such as temperature and moisture stress. Spike-mosses, like any other plants groups, may develop various mechanisms to adapt to those changes in temperature and moisture level by reducing growth rates, photosynthetic rates, mineral absorption and tissue regeneration, and by increasing concentrations of secondary metabolites (Jochum et al. 2007). However, these mechanisms may not be able to cope with all the anticipated severe climate change. Several scientists (Philips et al. 2006; Minteer and Collins 2010; Chen et al. 2011; Morueta-Holme et al. 2015) expect that to cope with severe climate change; plants will migrate to other areas with more suitable climatic-ecological requirements.

Selaginella Pal. Beauv. is the single remaining genus of vascular plants from the order Selaginellales, or mostly well-known as spike-mosses or lesser club-mosses. It has a wide range of distribution specialized on tropical regions of the world, rare in the temperate regions, and almost absent in the alpine zone. Selaginella species can be found in both very dry and very humid environments and in both open and shaded habitats. The tropical-hot and high humidity characteristics of climate in SEA is highly suitable for the wide distribution of Selaginella in this region. Selaginella involvens (Sw.) Spring. and Selaginella repanda (Desv. \& Poir.) Spring. are two examples of dry-adapted selaginellas grow on the rock crevices or surface of plants and physiologically dependent on atmospheric sources of water and nutrients. Which are released as water vapor or rain (Nadkarni 2010). Thus, we may expect that both water and temperature directly control relevant eco-physiological process influencing growth rates and species distribution (Nascimbene and Marini 2015).

Selaginella involvens is a typical species of highland that adapt to dry conditions; grows on cliffs, rocks crevices, and epiphytes on trees. In Java, It is usually found in the highlands (> $1000 \mathrm{~m}$ asl.), such as Mts. Sindoro-Sumbing (Setyawan 2012), Mt. Merapi (Setyawan et al. 2012, 2015a) and Mt. Lawu (Setyawan et al. 2013), and Dieng Plateau (Setyawan et al. 2015c), but it is sometimes found in lower altitude ( $500 \mathrm{~m}$ asl.), such as Mts. Sewu (Setyawan et al. 2015b), and Bromo Tengger Semeru National Park (Setyawan and Sugiyarto 2015). On the other hand, Selaginella repanda is a typical species of hilly lowland that adapt to dry conditions; it very easy to find in karstic mountain of Mts. Sewu (Setyawan et al. 2015b) and southern Java lowlands, although it can also rarely found in the higher altitude (500-1000 m asl.) (Setyawan et al. 2016). It usually attaches to the rocks and uses leaf litter as source of nutrients, with strong, pointed or tapered leaves, to adapt the dry condition.

In the last few decades, there was a marked increase of interest in the use of Species Distribution Models (SDM) (Merow et al. 2013; Fourcade et al. 2014). Empirically, these models were built by relating species occurrence data (either presence-only or presence-absence) to environmental predictor variables. These predictors can exert either direct or indirect effect on species, and must be selected optimally to reflect the three main types of influences on the species, i.e. (i) limiting factors related to species eco-physiology (e.g. temperature, water, soil composition); (ii) natural or human-induced disturbances, and (iii) resources (e.g. energy and water) assimilated by organisms (Guisan and Thuiller 2005). Since these environmental variables contain spatial data, it is best to manipulate it within a geographical information system (GIS) method. One of the most growing approaches of SDM is through the use of Maximum Entropy algorithms (Belgacem and Louhaichi 2013).

Maxent (Maximum Entropy Modeling) is a generalpurpose machine learning method with a precise and simple mathematical formulation, and it has some aspects that make it well-suited for species distribution modeling (Phillips et al. 2006). These approaches are based on presence-only data which are necessary since the true absence of species is difficult, and because false absence can decrease the reliability of the predictive models (Phillips and Elith 2013). Maxent can utilize different climatic scenarios to estimate the extent of occurrence of species (Beaumont et al. 2007). Therefore, allowing the evaluation of species' vulnerability to climate change (e.g., Rondinini et al. 2006; Botkin et al. 2007; Randin et al. 2008; Engler and Guisan 2009; Garavito et al. 2015). Scientists (e.g., Carter et al. 2007; IPCC 2014) tried to define the vulnerability to climate change as "the degree to which a system is susceptible to, or unable to cope with, adverse effects of climate change, including climate variability and extremes".

Assessments of species vulnerability consider the vulnerability as the extent to which a species (within a defined geographical region) is susceptible to harm from climate impacts (Schneider et al. 2007). These assessments are useful to identify which species are likely to be impacted significantly by climate changes, and to enhance the understanding of why they may be vulnerable (Belgacem and Louhaichi 2013). Climate correlates to 
species in the range of both horizontal and vertical spatial scales. Horizontally, species distribution range at a large extent is shaped by macroclimate. Nevertheless, at the smaller extent, topography shaped the macroclimate to produce an altitudinal climatic gradient along the local elevation (Mandar et al. 2008). Whether considering species ranges in horizontal or vertical terms, climate imposes range limits either indirectly, by mediating biotic interactions such as competition, or directly, through physiological constrains on survival or reproduction (Gavin and $\mathrm{Hu}$ 2006). S. involvens and $S$. repanda are two species which generally found at opposing range of elevation. $S$. involvens is often found in high-altitude areas, while $S$. repanda is usually found at lower-altitude areas (Setyawan et al. 2016). Therefore, we assumed that there will be altitudinal barrier between these species, which in this case will limit the redistribution mechanism of each species to adapt the climate change projections.

This study model the potential geographic distribution of $S$. involvens and $S$. repanda under present climate condition, and models the impacts of projected climate change on their potential distribution. We generate future predictions under four detailed bioclimatic scenarios (i.e., RCP 2.6, RCP 4.5, RCP 6.0, and RCP 8.5) over three-time intervals $(2030,2050,2080)$, which combine a range of climatic factors. Quantifying the potential impacts of a range of climatic scenarios offers the opportunities to develop understanding the response of plants to climate change, and develop mitigation strategies under all projected scenarios of climate change to effectively conserve biodiversity.

\section{MATERIALS AND METHODS}

\section{Study area}

The study was conducted to model the effect of climate change in Southeast Asia (SEA) region. SEA region consists of eleven political countries which can be divided into mainland SEA (i.e., Cambodia, Laos, Myanmar, Peninsular Malaysia, Thailand, and Vietnam) and maritime SEA (i.e., Indonesia, Phillippines, East Malaysia, Brunei, Singapore, and East Timor) (United Nations 2015). The geographic scope of this study includes the region of approximately $23.5{ }^{\circ} \mathrm{N}$ to $10{ }^{\circ} \mathrm{S}$ latitude and $97{ }^{\circ} \mathrm{E}$ to 141 ${ }^{\circ} \mathrm{E}$ longitude (Figure 1.). Southeast Asia covers an area of roughly 4,687,481 square kilometers with Mount Hkakabo in northern Myanmar on the border with China, at 5,881 meters, as the highest peak of mainland Southeast Asia (Leinbach and Frederick 2015). This vast altitudinal range and wide areas create a wide variation in climatic, physiographic, topographic, and edaphic conditions resulting in rich biodiversity.

SEA region has been experiencing climate change and its impact; Average annual surface temperature increased by $0.5-1.1^{\circ} \mathrm{C}$ during the period $1901-2005$ (NIC 2009). Similarly, climate model projection shows temperature increase by approximately $1^{\circ} \mathrm{C}$ through 2030 , and will keep increasing through the remainder of the $21^{\text {st }}$ century (IPCC 2014). Although, there is no clear projection in precipitation patterns in the region, climate model suggests that net precipitation rates will increase across the region, but there will likely be local decrease that will vary geographically and temporally (NIC 2009).
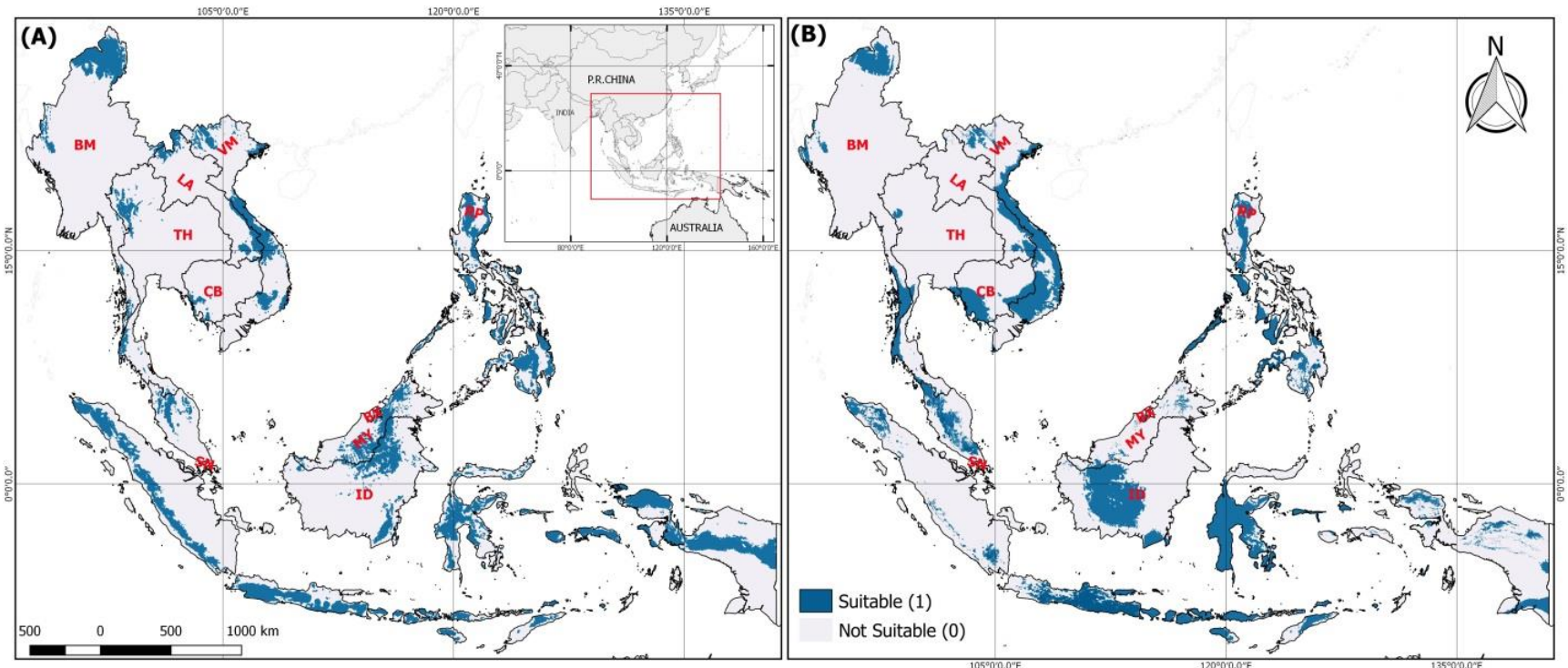

Figure 1. Predicted potential distribution of (A) Selaginella involvens, (B) Selaginella repanda under current climate condition 


\section{Procedures}

Species locality data

Occurrence data for $S$. involvens and $S$. repanda were compiled from two main sources. The first source of locality points for both species was from field survey conducted in all Indonesian provinces in Java island between July 2007 and January 2014. The specimens were identified using several references on Selaginella of the Malay Archipelago and adjacent regions, both early (Alston 1934, 1935a,b, 1937, 1940) and latest literature (Wong 1982, 2010; Tsai and Shieh 1994; Li and Tan 2005; Chang et al. 2012; Zhang et al. 2013), as well as our previously publications (e.g., Setyawan 2012; Setyawan et al. 2012, 2013, 2015a,b,c; Setyawan and Sugiyarto 2015).

Altogether, 126 occurrence points of S. involvens and 68 occurrence points of $S$. repanda distributed in central, western and eastern region of Java island were collected using Garmin eTrax GPS series. None of error-correction step was conducted to adjust these data as we ensuring the accuracy of these points were less than $0.01 \mathrm{~km}$ at the time of data collection (www.garmin.com). Our judgment was based on allegation stated by Montgomery et al. (2011), that said the level of telemetry error on modern GPS (normally between $0.01 \mathrm{~km}$ and $0.05 \mathrm{~km}$ ), which is much smaller than the resolution of the predictor variables used in this study, has a little effect on the accuracy of predicted models. The second source of occurrence data of both species was from Global Biodiversity Information Facility (GBIF 2017) database which provides freely accessible occurrence points on its website (http://www.gbif.org). Despite the use of "geo-referenced points only" filter on the data acquiring process from this website, several adjustments must be conducted. All coordinates were verified carefully and error that may occur were corrected using Google Earth software (Google Earth Pro 2017). Data records which lack coordinate were geo-referenced using Biogeomancer Workbench guided by locality description on each datum (Guralnick et al. 2006). Ambiguous data (i.e., those that does not have specific locality and cannot be geo-referenced) were removed, then the remaining 809 occurrence points of $S$. involvens and 124 points of $S$. repanda were combined with the occurrence points collected from the field survey.

The recent availability of biodiversity and environmental datasets globally (e.g. gbif and bioclim) was the main factor in the increasing number of regional to continent-wide SDM study (Hijmans et al. 2005; Kozak et al. 2008). Nevertheless, such datasets derived from collection of records and/or opportunistic observation often exhibit a strong geographic bias (Stolar and Nielsen 2015). Sampling bias correction was performed to minimize the strong influence of such bias to the modeling prediction ability (Fourcade et al. 2013, 2014). For this study, we conducted two out of five option methods of sampling bias correction proposed by Fourcade et al. (2014): (i) We conducted systematic sampling (often called spatial filtering) by creating a grid of a $2 \mathrm{~km} \times 2 \mathrm{~km}$ cell size and randomly removed the occurrence points existed, until one point of occurrence left per grid cell. This size of this grid cell was not meant to represent the approximate of species' dispersal capabilities, but rather to reduce the geographic biases by modified the $10-\mathrm{km}$ radius rule proposed by Pearson et al. (2007); Anderson and Raza (2010). The grid cells creation and points removal were conducted using QuantumGIS ver 2.18.10. (ii) We created bias file grids which later can be fed to Maxent software ver. 3.4.1by its setting options (Dudik et al. 2005; Elith et al. 2010; Phillips et al. 2017). Bias file is a probability surface represented by cell value which reflect the intensity of sampling effort across the area of study and gives a gradual weight to random background data used for modeling. Creating bias file can also be estimated using the aggregation of occurrences from closely related species (Phillips et al. 2009). However, in most real modeling situation, this information is limited. Thus, following Elith et al. (2010), we produced a Gaussian kernel density map of the occurrence locations, then rescaled it from 1 to 20 to be derived from bias file instead of using our knowledge to create artificially bias file (Fourcade et al. 2014). As the distribution of both species occurs in different countries (of different areas), we used the political state boundary extracted from Global Administrative Areas website (www.gadm.org/), to limit the background areas for the species.

\section{Environmental and bioclimatic data on current climate condition}

Selecting the predictors to build the model in this study was based on the model-driven selection process. Modeldriven selection will use all possible predictors and select those with greatest importance in the model to be considered as the main factor affecting the distribution of species, rather than expert-driven selection where the expert priory will choose the predictors expected to directly affect the distribution of the species (Fischer 2011). We first collected 19 bioclimatic layers ver. 2.0 and one altitude layer. The 19 grid-based bioclimatic layers were downloaded form WorldClim Bioclimatic datasets website (www.worldclim.org). Bioclimatic layers were generated by interpolating the average monthly climate data from between 9,000 and 60,000 weather stations at approximately $1 \mathrm{~km}^{2}$ spatial resolution (Fick and Hijmands 2017). Altitude layer was collected from the same website with the same spatial resolution. To use in Maxent software, these layers must be processed through several steps including image cutting to the extent of area study, resampling data, and file converting from tif format to .asc format. Land use/land cover changes, human disturbances, species dispersal or biotic interaction changes were not taken into account as the availability of these data were limited.

It is widely known that many climate variables are highly correlated with each other. Even though including all these variables will not affect the predictive quality of Maxent model greatly (Elith et al. 2011), it does, however, significantly limit any inference of the contribution of any correlated variables since Maxent often excludes all other highly correlated variables from being incorporated (Van Gils et al. 2012, 2014). Since this study is interested in interpreting how each variable contributes to the model, we 
decided to reduce autocorrelation of the climatic variables by removing the highly correlated variables. We used the SDM toolbox ver 2.0 (Brown 2014) in ArcGIS ver. 10.1 to perform the calculation and automatically removed each one of two correlated variables. The remaining six bioclimatic variables (i.e., bio_1, bio_2, bio_3, bio_4, bio_12, and bio_19) plus altitude layer were then used as predictors variables to model the potential distribution of $S$. involvens and $S$. repanda under current and future climate condition.

\section{Environmental and bioclimatic data on projected future climate condition}

Future predictive maps for potential redistribution of $S$. involvens and $S$. repanda were generated using the future climate projection datasets provided freely by CGIAR Research Program on Climate Change, Agriculture, and Food Security (www.ccafs-climate.org). The general circulation model which often used in climate modeling was originally has a spatial resolution at 100 to $200 \mathrm{~km}^{2}$. To achieve the 30 arc seconds resolution $\left(1 \mathrm{~km}^{2}\right)$, CCAFS downscaled it using the delta method by interpolating it from its original resolution (Ramirez and Jarvis 2008). We selected four RCP (Representative Carbon pathways), which represents the future greenhouse gas (GHG) trajectories, namely RCP 2.6, RCP 4.5, RCP 6.0, and RCP 8.5 for three different time periods (2030, 2050, and 2080). In this study, we selected the HadGEM2-CC (Hadley Global Environment Model-2 Carbon Cycle) global circulation model, which was developed by the Hadley Center, United Kingdom (Collins et al. 2011). HadGEM2CC model has been used to perform all the CMIP5 (Coupled Model Inter-comparison Project Phase 5) centennial experiments including ensembles of simulations of the RCPs (Shrestha and Bawa 2014). RCP 2.6 assumes that global GHG will increase slowly to reach its peak at $3.1 \mathrm{~W} / \mathrm{m}^{2}$ in between 2010-2020, with emissions declining substantially thereafter to $2.6 \mathrm{~W} / \mathrm{m}^{2}$ by the year 2100 (Van Vuuren et al. 2007; Moss et al. 2010). Emissions in RCP 4.5 is assumed to be stabilized at $4.5 \mathrm{~W} / \mathrm{m}^{2}$ by the year 2100 due to the employment of a range of technology and strategies to reduce GHG emissions (Clarke et al. 2007). Likewise, the emissions in RCP 6.0 is projected to reach its peak around 2080 and stabilizes by the year 2100 at 6.0 $\mathrm{W} / \mathrm{m}^{2}$. In RCP 8.5 , emissions continue to rise throughout the $21^{\text {st }}$ century, reaching around $8.5 \mathrm{~W} / \mathrm{m}^{2}$ as the highest value by the end of the century (Riahi et al. 2011). The same altitude layer was used since this variable was static variable that does not change with time.

Despite the widely usage of global climate model (GCM) to provide the basis for climate change impacts assessments of climate change at local to global scales and to be used as primary source of information for constructing climate scenarios, these models exhibit systematical error (biases) due to the limited spatial resolution, numerical schemes, simplified physics and thermodynamic processes, or incomplete knowledge of climate system processes (Ramirez-Villegas et al. 2013). Therefore, in this study, we implemented the bias correction data provided by CGIAR-CCAFS under two different calibration approach: (i). The Change Factor (CF) approach, where the raw GCM outputs current values are subtracted from the future simulated values, resulting in "climate anomalies" which are then added to the present day observational dataset (Tabor and Williams 2010). 2). (ii) The Quantile Mapping (QM) approach, it was selected to complement the $\mathrm{CF}$ approach, since the $\mathrm{CF}$ works well for only more non-stochastic variables (i.e., temperature). Thus, a more sophisticated approach for bias-correcting stochastic variables such as this approach (e.g., precipitation and solar radiation) was needed.

\section{Maxent modeling}

We used freely available Maxent software ver. 3.4.1 (Philips et al. 2017b) to model the potential distribution of $S$. involvens and $S$. repanda habitat under current climate condition and assess its changes under the effect of projected future climate condition. Maxent has been proved to gives the best results among other modeling algorithms available on the basis of presence-only (PO) data and environmental variables (Philips and Dudik 2008; Summers et al. 2012). The popular utilization of Maxent is due to the higher predictive accuracy than any other methods (Elith et al. 2006; Summers et al. 2012). Maxent also performs well to estimate the effect of climate change on the potential shifting range of species (Kou et al. 2011; Johnston et al. 2012; Duan et al. 2016), with more than 1000 published distribution modeling has been conducted since 2005 using Maxent software (Merow et al. 2013; Fourcade et al. 2014).

Despite the fact that Maxent has been shown to give robust and reliable results by just using default settings (Phillips et al. 2008), we modify several parameter values to adjust the calculation with our presence data and predictor variables. The adjusted parameter values were: maximum iterations were set 5,000 to allow the model to have adequate time for convergence, convergence threshold was set to $1 \times 10^{-6}$, and ten replicated runs (the averaged value is the one used as the result) with "crossvalidate" as the replicated run type. Using "cross-validate" means to split the data ten times ( $10 \%$ per partition), train the model ten times on $90 \%$ of the data, and test it each time on the $10 \%$ partition alternately. Assuming that both selaginellas are responded directly to the predictors (vs to correlated factors) and to avoid overfitting (Elith et al. 2010), we decided to smooth the Maxent by choosing only hinge features to model both $S$. involvens and $S$. repanda. We doubled the default "regularization multiplier" value as we assumed that it was necessary because we use a large collection of species from diverse regions to be projected to different climate condition (Elith et al. 2006; Merrow et al. 2013; Radosavljevic and Anderson 2013). Furthermore, increasing the "regularization multiplier" value as high as 2.00 or 40.00 are necessary to reduce over-fitting to lower levels (Radosavljevic and Anderson 2013). We used the "projection" feature to predict the impact of future climate change to the redistribution of climatically suitable habitat for both species (Van der Wall et al. 2009). 


\section{Data analysis}

Maxent will produce predictive maps which represent potential maps of species distribution, these maps show where the ecological niche is potentially suitable for the species across the study area. The degrees of potential suitability are linearly scaled between 0 (lowest) to 1 (highest) probability 1 (highest) (Philips and Dudik 2008). In addition, Maxent calculates the bioclimatic' relative contribution to the model and how much of these variables affect the Maxent prediction. Alternate estimation of variable importance was also collected by running the jackknife test in Maxent. The results of jackknife test show which variable have the most useful information by itself and which variable appears to have the most information that is not present in the other variables.

The predictive maps, which by default are in ASCII format, containing the probability were further analyzed using QuantumGIS software ver. 2.18.11 (QGIS 2017). To allow us to quantify and compare the redistribution of suitable habitat, we conducted binary calculation (suitable vs unsuitable) by using selected threshold rule. Selecting threshold rule is one of the many possible biases in SDM (Phillips and Dudik 2008; Nenzen and Araujo 2011; Bean et al. 2012; Syfert et al. 2013). Therefore, in determining the threshold rule, one should avoid arbitrariness and should consider the relative importance of commission and omission error (Hernandez et al. 2008; Nenzen and Araujo 2011; Liu et al. 2013). Considering to reduce omission error as more important determinant than commission error, Norris (2014) in his study proposed "minimum training presence" or "fixed cumulative value 1 " to be the most appropriate rule. However, Liu et al. (2016) stated that for rare species, omission errors might be weighted more than commission errors but when considering a more common species, commission errors are more important than omission errors. Therefore, following Liu et al. (2016) we selected "maximum training sensitivity plus specificity" as threshold rule since this rule produces lower commission errors.

Maxent will calculate an area under the receiver operating characteristic (ROC) curve (AUC) as a way to evaluate model performance. Several studies (e.g., Pearson and Dawson 2003; Pearson et al. 2007; Rodder et al. 2010; Jiménez-Valverde A. 2012) have used AUC value to evaluate their model and to convince that their model can not be categorized as a merely random prediction. AUC value range between 0.5 and 1.0 , with 0.5 indicating that the model is no better than random prediction; values below 0.7 are low, values between 0.7 and 0.8 are good, and values $>0.9$ indicate high discrimination, or it means that the model is far better than random prediction. Even though the AUC was written as the established method for assessing the fitness of the model in some papers, unfortunately, it is also proved wrong by Lobo et al. (2008); Bahn and McGill (2013); and Aguirre-Gutiérrez et al. (2013). These studies demonstrated that AUC does not provide useful information for assessing SDM performance. Therefore, in this study, the additional evaluation of the model was conducted using True Skill Statistic (TSS) as it has been proved theoretically and empirically better than AUC and also better than Kappa Statistic in measuring the performance of species distribution models (Allouche et al. 2006).

\section{RESULTS AND DISCUSSION}

\section{Results}

Analysis of variable contributions

Our models indicated that, for each species, there are two different variables which provide the highest relative contribution to explain the predicted geographic distribution of $S$. involvens and $S$. repanda's suitable habitat in SEA region (Figure 1). Altitude was the highest contributor variable in the distribution pattern of $S$. involvens' suitable habitat $(27.3 \%)$, while for $S$. repanda, average annual precipitation (bio_12) was the highest contributor variable contributed $36.2 \%$ to the model. Two precipitation variables (bio_19 and bio_12) explained in total of $38.7 \%$ of the variation in the distribution pattern of $S$. involvens' suitable habitat. Another $66 \%$ contribution to this model was apparently from temperature variables (bio_1, bio_2, bio_3, bio_4), with the highest contribution was only $10.1 \%$ (Table 1 ). For $S$. repanda model, another two significant contributor variables were Annual temperature (bio_1) and mean diurnal range (bio_2) which contributed in total of $47.7 \%$. Other variables (alt, bio_3, bio_4, and bio_19) appeared to have no significant contribution to this model with only less than $20 \%$ of contribution in total (Table 1).

Alternate estimation of variable importance was also calculated through the jackknife test. The results of jackknife test show which variables have the most useful information by itself and which variables appear to have the most information that is not present in the other variables (Phillips et al. 2008). The Maxent models's jackknife test in this study shows a different conclusion on the importance of each variable for both species. The jackknife for $S$. involvens model shows that altitude has the highest gain when used in isolation, which therefore appears to have the most useful information by itself (Figure 2). Furthermore, the environmental variable that decreases the gain the most when it is omitted is annual precipitation (bio_12), which therefore appears to has the most information that is not present in the other variables. For $S$. repanda's model, the jackknife test shows that temperature seasonality (bio_4) variable was both the highest gain when used in isolation and decreases the gain highest when it is omitted. This result indicates that for the $S$. repanda model, bio_4 variable has the most useful information which is not present in the other variables.

\section{Models of present-day distribution}

The potential present-day distribution of $S$. involvens and $S$. repanda's suitable habitat, as derived from Maxent (Phillips and Dudik 2008; Elith et al. 2011; Phillips et al. 2017), are shown in Figure 1. These models were built using 327 unique locality points of S. involvens and 190 locality points of $S$. repanda which were the remaining points after spatial filtering applied (see method). Based on 
our models, approximately $12 \%\left(561,424.7 \mathrm{~km}^{2}\right)$ of the SEA area is suitable for $S$. involvens, within predicted altitudinal range of between $1050 \mathrm{~m}$ asl. to $3500 \mathrm{~m}$ asl. (Figure 3). The suitable area for $\mathrm{S}$ involvens in mainland SEA spread patchily in Vietnam, Burma, Thailand, Laos and Peninsular Malaysia, with small predicted suitable area in Cambodia. Meanwhile, in maritime SEA the predicted suitable habitat for $S$. involvens spread in all of big islands of Indonesia (Sumatra, Java, Sulawesi, Borneo and Papua), also appears in Lesser Sunda islands and most of the south Maluku islands. Additionally, the predicted suitable habitat also appears in almost all of the Philippines archipelago. Furthermore, our model predicted there are approximately $15 \%\left(687,412.1 \mathrm{~km}^{2}\right)$ of $S$. repanda's suitable habitat in SEA region, spread mostly in lowland areas between $50 \mathrm{~m}$ asl. to $1100 \mathrm{~m}$ asl. (Figure 3). The predicted suitable habitat of $S$. repanda in mainland SEA spread across north to south Vietnam, adjoining with Laos national border, and also spread patchily in Burma, Cambodia, and Peninsular Malaysia (Figure 1). The model predicted a very small suitable habitat for $S$. repanda in Thailand. In the maritime SEA, the predicted suitable areas spread across big islands of Indonesia (Sumatra, Java, Borneo, Sulawesi, and very small suitable area in Papua). Additionally, the predicted suitable habitat of $S$. repanda appears in most of the Philippines archipelago.

Table 1. Percentage of variable contribution to the final model

\begin{tabular}{|c|c|c|c|}
\hline \multirow[b]{2}{*}{ Variables } & \multirow[b]{2}{*}{ Description } & \multicolumn{2}{|c|}{ Contribution (\%) } \\
\hline & & $\begin{array}{c}\text { S. } \\
\text { involvens }\end{array}$ & $\begin{array}{c}S . \\
\text { repanda }\end{array}$ \\
\hline Altitude & & 20.3 & 5.9 \\
\hline Bio_1 & $\begin{array}{l}\text { Annual mean temperature } \\
\left({ }^{\circ} \mathrm{C}^{*} 10\right)\end{array}$ & 15.6 & 32.9 \\
\hline Bio_2 & $\begin{array}{l}\text { Mean diurnal range (mean } \\
\text { of monthly (max temp - } \\
\text { min temp)) }\end{array}$ & 22.5 & 14.8 \\
\hline Bio_3 & Isothermality & 0.7 & 4.8 \\
\hline Bio_4 & $\begin{array}{l}\text { Temperature seasonality } \\
\text { (standard deviation*100) }\end{array}$ & 9.2 & 3.7 \\
\hline Bio_12 & Annual precipitation & 14.4 & 36.2 \\
\hline Bio_19 & $\begin{array}{l}\text { Precipitation or coldest } \\
\text { quarter }\end{array}$ & 17.2 & 3.1 \\
\hline
\end{tabular}
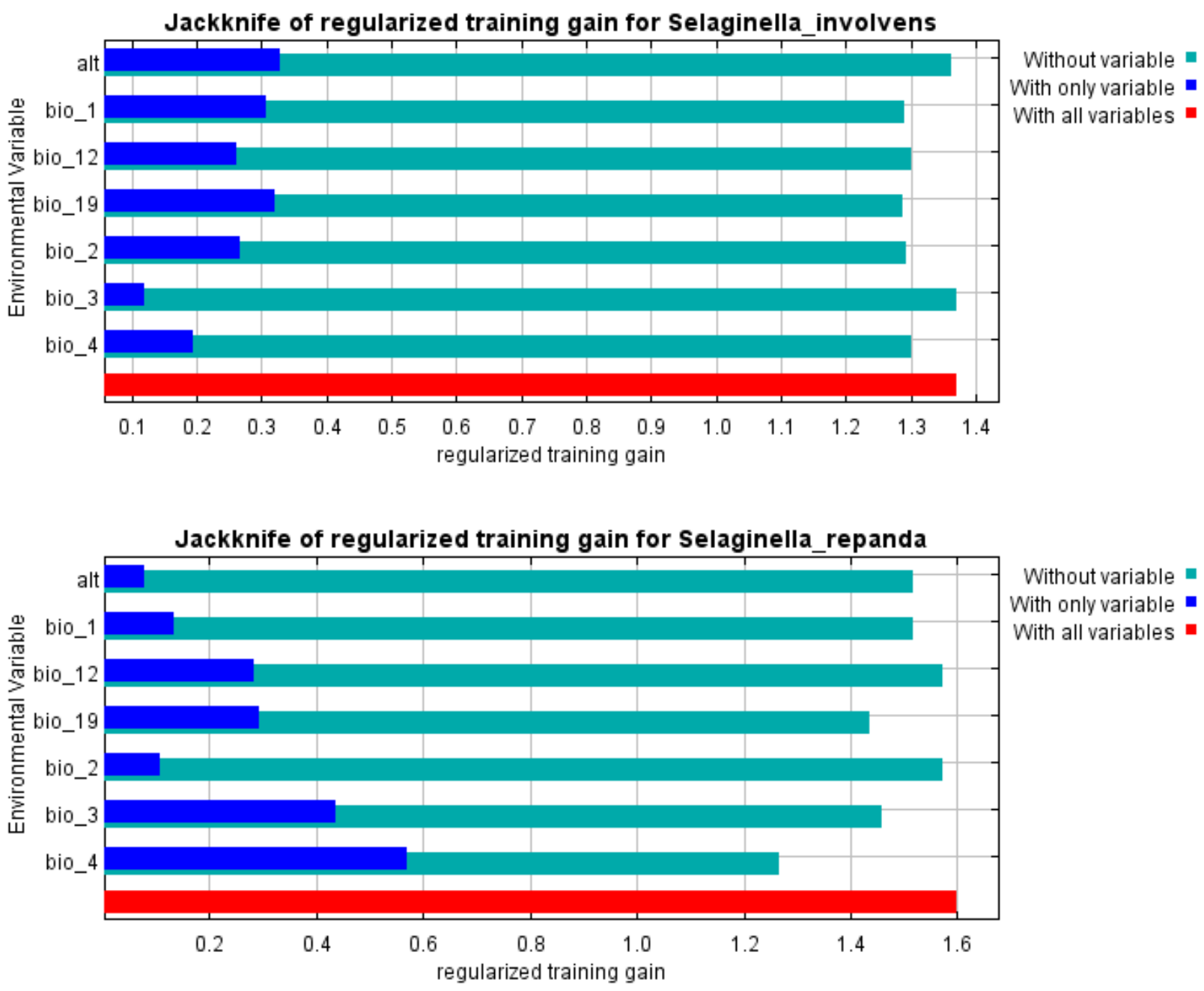

Without variable With only variable With all variables $\mathbf{~}$

Figure 2. Results of jackknife test of relative importance of predictor variables for Selaginella involvens and Selaginella repanda 


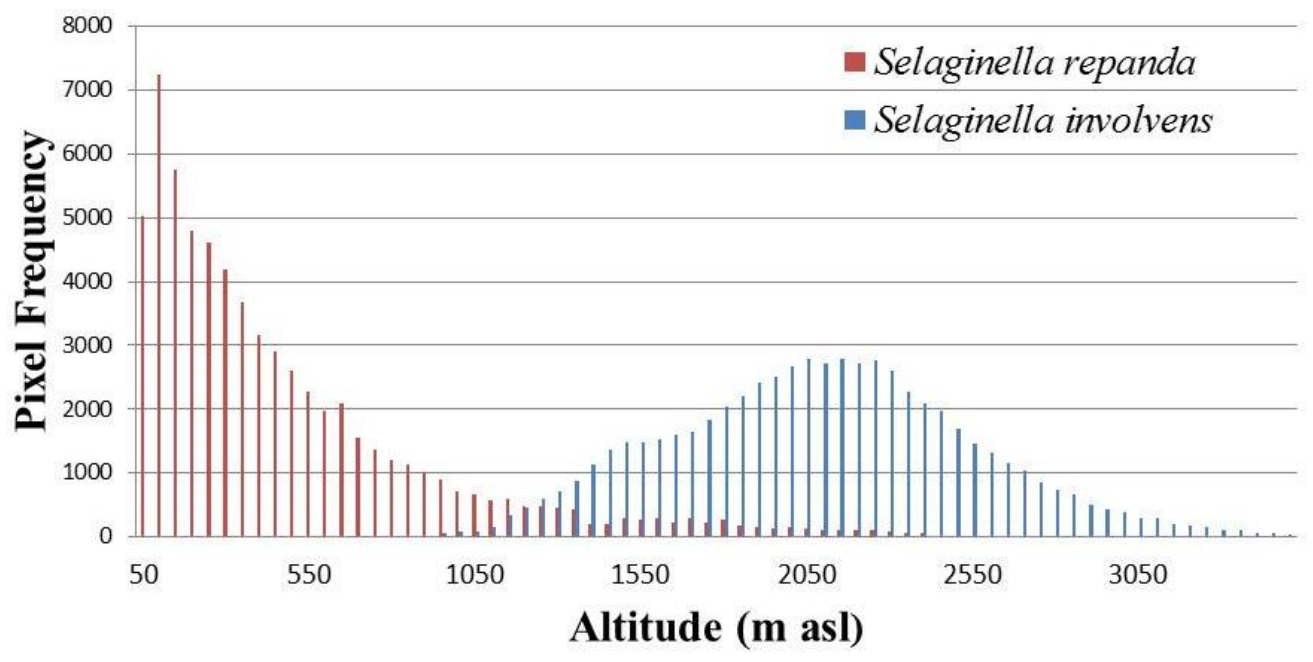

Figure 3. Predicted altitudinal distribution of Selaginella involvens and Selaginella repanda suitable habitat under current climate condition

The predicted suitable habitat of $S$. involvens and $S$. repanda under current climate condition were mainly concentrated in Java island, covering both the highland and lowland areas, respectively. The vast altitudinal gradient in this island creates a broad diversity in climatic, physiographic, and edaphic condition which become the major factors in influencing the development of the models. Our model predicted about $28,266.5 \mathrm{~km}^{2}(21.1 \%)$ areas are suitable for $S$. involvens which spread mainly on highland areas across this island, ranged from $1100 \mathrm{~m}$ asl. to about $3000 \mathrm{~m}$ asl. On the other hand, the suitable habitat of $S$. repanda predicted mainly on the lowland, spread across the island in a total area of $38,037.8 \mathrm{~km}^{2}(28 \%)$. Nevertheless, several small patches of predicted suitable areas for both species also appear overlapped in between the lowland and highland in a total area of $5423.6 \mathrm{~km}^{2}$.

Despite the fundamental problem when using AUC (Area Under the Curve) for validation (Franklin 2010; Hijmans 2012), we retrieved the AUC value of 0.848 for $S$. involvens' model and the AUC value of 0.910 for $S$. repanda's model to illustrate that the predictions in this study were far better than random prediction and to indicate that the selected variables have described the distribution of both selaginella acceptably. Furthermore, additional evaluation of the models was conducted using True Skill Statistic (TSS) to give further confidence in the output of these models. The TSS value of 0.81 and 0.85 for $S$. involvens and $S$. repanda's models, respectively, give the impression that the models built in this study have a very good degree of agreement ( $\mathrm{Li}$ and Guo 2013). Several studies also demonstrated the use of Kappa statistic for Maxent validation (e.g. Aguirre-Guiteres et al. 2013; Duan et al. 2014), but, regarding of the Kappa value, it is highly correlated to prevalence of the locality points and the size of the study area (Lobo et al. 2008). Consequently, this would generate some sort of bias or misunderstanding, for example, if one uses a small study region or if the locality points are localized in a small area and the prevalence is small, one would get a high Kappa value. Moreover, Kappa, just like AUC, is more reliable if we use PA (Presence-Absence) model, due to the fact that both AUC and Kappa are weighting omission and commission errors equally. Thus, in case of this study where presence only data were used, we thought that the use of Kappa statistic is not suitable.

\section{Potential impact of the future climate change scenarios}

The potential impact of several climates changes scenarios on the predicted suitable habitat is illustrated in Figure 4. Across all scenarios in three different periods of time, the predicted climatically suitable areas were predicted to decrease significantly (Figure 5). Under the RCP 2.6 (lowest GHG emission prediction) future climate scenario, the climatically suitable area for $S$. involvens will likely to continuously decrease by approximately $10 \%$ in the year 2080 , while about $17 \%$ of $S$. repanda's suitable habitat will be lost in the same period of time. Likewise, by the end of 2080, there will be a gradual decrease of predicted suitable area under RCP 4.5 and RCP 6.0 (medium GHG emission prediction) by maximum $20 \%$ and $22 \%$ for $S$. involvens and $S$. repanda respectively. Furthermore, RCP 8.5 future climate scenario is predicted to have the most impact on the decrease of climatically suitable habitat for both species. Approximately, 27\% of current suitable area for $S$. involvens will be lost, while $29 \%$ of current $S$. repanda's suitable habitat will also be vanished by the end of 2080. The continuously declining area of climatically suitable area for both species occurs gradually at the edge of every patch of modeled area. Thus, visual assessment can not clearly reveal which nation will likely to undergo the most suitable habitat loss. However, we can easily identify the progressive process of declining in Borneo and Sulawesi islands. 


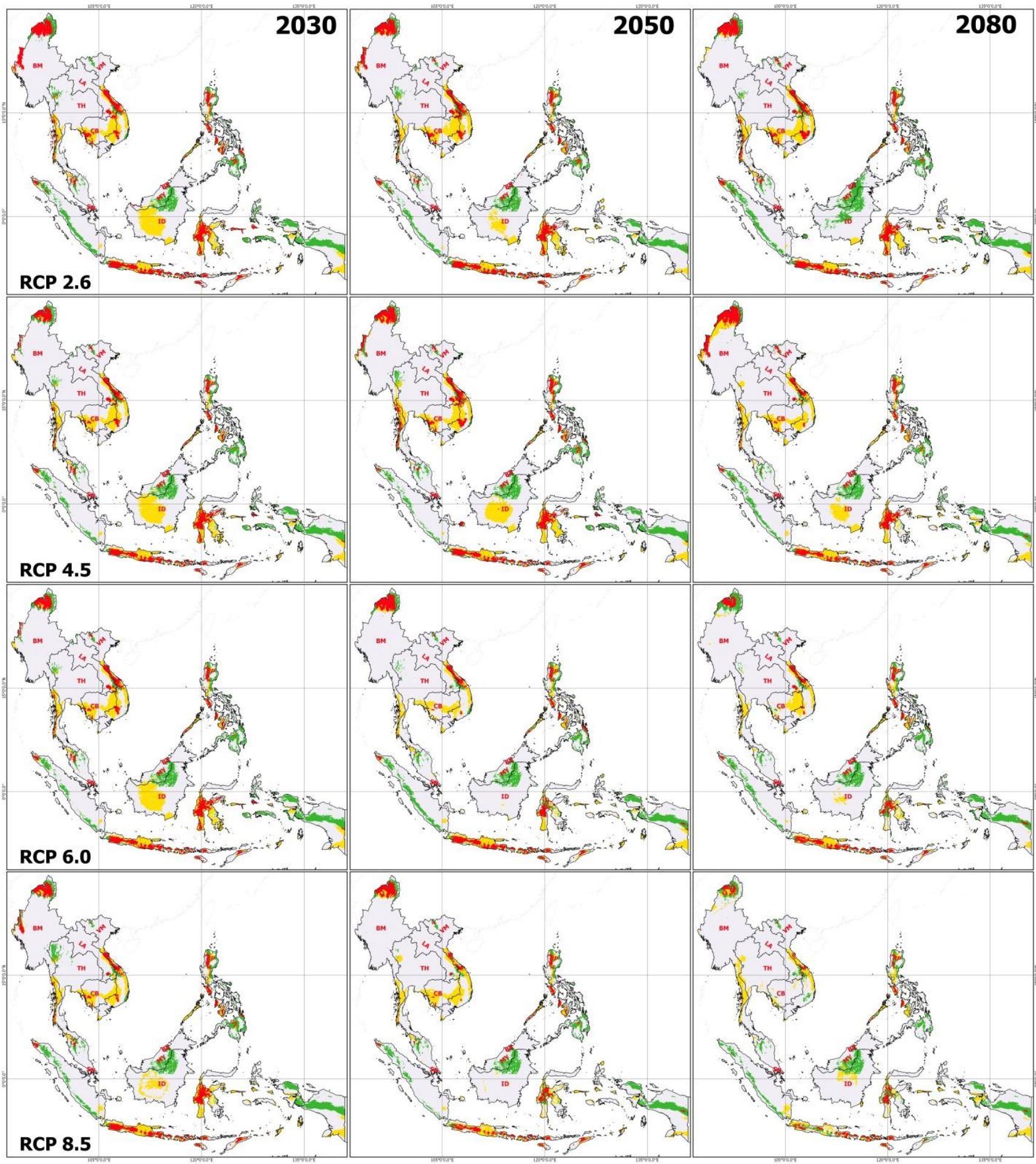

$500 \quad 0 \quad 500 \quad 1000 \quad 15002000 \mathrm{~km}$

Suitable for Both Species

Suitable for Only S. involvens

Suitable for Only S. repanda

Figure 4. Prediction of future distribution under future climate projections

\section{Discussion}

This study represents the primary attempt to model the distribution of $S$. involvens and $S$. repanda's suitable habitat under current climate condition and to model its redistribution under the effect of future climate change scenarios in SEA region. Our models predict the potential distribution of climatically suitable habitat for both species, under current climate condition, are distributed in all of SEA region countries. The distribution of suitable habitat for $S$. involvens mostly appears in highland areas, while for $S$. repanda appears mainly in lowland areas. Nevertheless, there are also areas which predicted suitable for both species. 


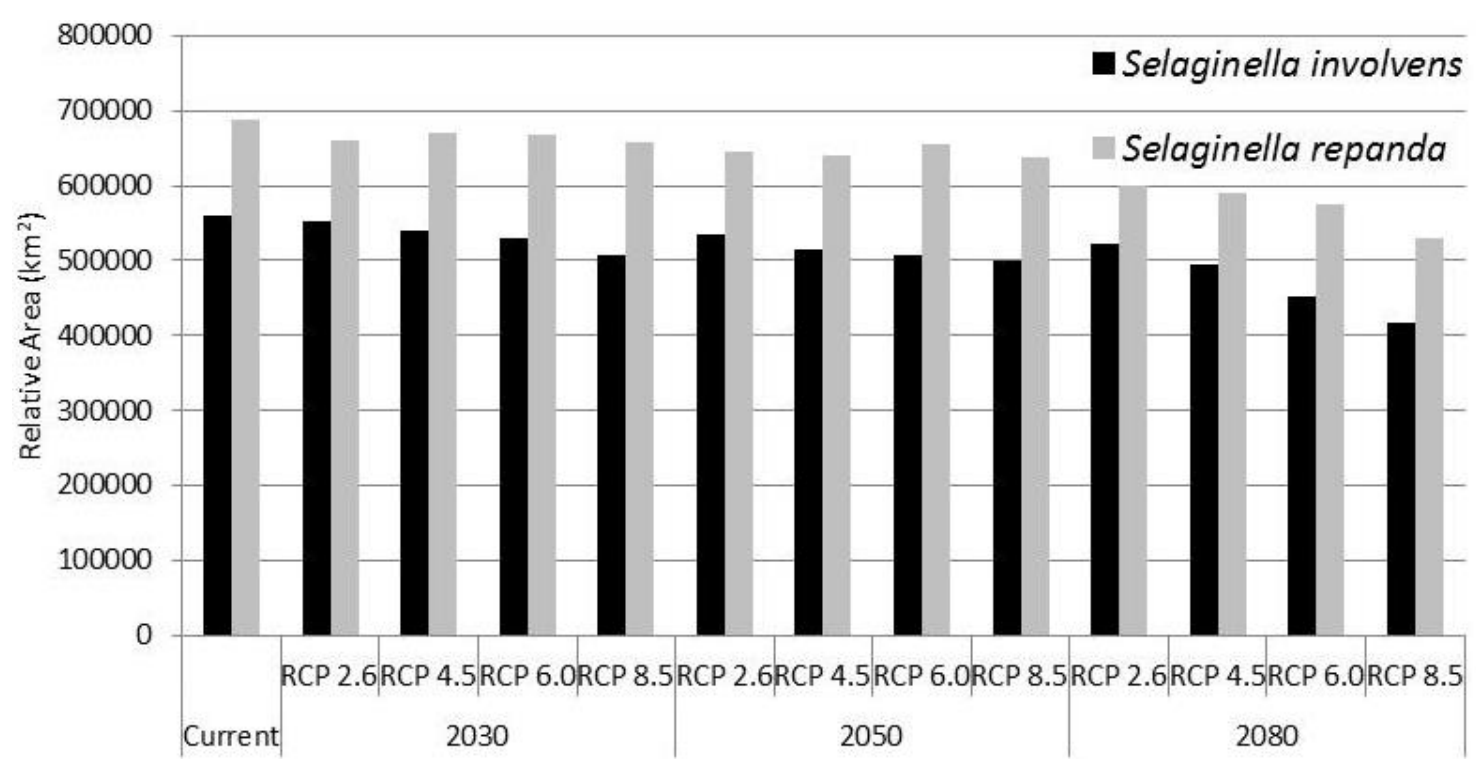

Figure 5. Estimated areas of predicted distribution of Selaginella involvens and Selaginella repanda suitable habitat

The predictive maps represent the potential distribution of climatically suitable habitat for both species, not the actual distribution of the species. The maps illustrate where the ecological niche is potentially suitable for both species. In the predicted suitable area, the species may not actually exist, for the following reasons (i) The vegetation has been drastically altered causing the predicted areas are no longer suitable for the species (e.g. deforestation, agriculture). (ii) The commission error occurs as the result of inaccuracies and weak resolution in the recorded environmental variables. It should be noted that the climate data were produced by modeling the original climate data from a network of weather stations. (iii) The micro-climate factors are not included in the models. (iv) The current environmental variables dataset have not yet represented the unique environmental condition which necessarily drive the occurrence of the species. (v) Inaccuracy of locality data. However, in the case of this study, the last two of these points may not influence our model strongly. Inaccuracy of locality may not greatly influence our model, because these data have been verified carefully by several correction bias methods (see method). To verified the robustness of the models we may look insight into whether the climatic variables used to build the models are in conjunction with the climatic variable proven to influence the establishment and the existence of species used in this study, and we may look into the comparison of the predictive maps under current climatic condition with the historical data of geographical distribution of both species.

Both $S$. involvens and $S$. repanda are epiphyte plants which derive its moisture and nutrients from the air, rain, or from accumulated debris around it (Everhart et al. 2009). The performance, survival, and distribution of epiphytes are dependent on stand density, microclimate, distance from seed source, tree size and species, type and history of disturbance, population dynamics of epiphytes and trees, and epiphyte physiology (Hietz 1999; Sayago et al. 2013). At the local scale, many study have shown that the host's characteristics and morphology which related to the ability to provide larger area of establishment and colonization, longer period of exposure to light, moisture retention, and better epiphyte-host network structure (e.g. Flores-Palacios and García-Franco 2006; Burns 2007; Zhang et al. 2010; Koster et al. 2014; Rosell et al. 2014) are another important factors influencing the existence of epiphyte plants. Nevertheless, at the given scale of analysis in this study, climate has been assumed as the principal factor controlling species distribution and in dynamic equilibrium with the climate regime (Guisan and Thuiller 2005; Ellis et al. 2007; Zots 2007). In terms of climate condition, the survival and distribution of epiphytes are highly influenced by annual temperature and total precipitation (Eaton and Ellis 2012). Thus, the bioclimatic variables included in this study to build the models were in line with the knowledge about the climatic factors influencing the occurrence of both species.

Similarly, comparing the predicted distribution of climatically suitable habitat of $S$. involvens and $S$. repanda in the countries within the SEA region, with the historical occurrence of both species reported in several studies and documents will represent the level of robustness of this study's results. Out of 11 countries in SEA region, our model predicts the existence of climatically suitable area for $S$. involvens in all of these countries. The studies and documents confirmed the occurrence of $S$. involvens in this region were Spring (1843), (Tagawa 1973), and USDA (2002). Winter and Amoroso (2003), Chang et al. (2012) for Republic in the Union of Myanmar (Burma). Cosico 
(1972), Alston (1935b), Lasalita-Zapico (2011), Chang et al. (2012), Tan (2013), and Marjorie and Inocencio (2015) in the Philippines. Spring (1843), Newman et al. (2007) and Chang et al. (2012), in Laos. Spring (1843), Chang et al. (2012), Zhang et al. (2013) and Zhou et al. (2015) in Cambodia. Tsai and Shieh (1994), Chang et al. (2012), Nguyen et al. (2012), Zhou and Zhang (2015) and Zhou et al. (2015) in Vietnam. Boonkerd and Ratchata (2002) Jin et al. (2007) and Chang et al. (2012) in Thailand. Parris et al. (2010) and Youguang and Tan (2013) in Peninsular Malaysia and Singapore. In big islands of Indonesian archipelago, S. involvens occurred in Borneo (Spring 1843; Chang et al. 2012), Sulawesi (Spring 1843; Tagawa 1963, 1973; Tsai and Shieh 1994), Java (Spring 1843), and the Lesser Sunda islands (Spring 1843; Tagawa 1963, 1973; Chang et al. (2012). Nevertheless, recent literature study reported that only in Java island, this species occurrence records had been updated.

On the other hand, the documents confirmed the occurrence of $S$. repanda in Southeast Asia were Tagawa (1973), This species can be found in Myanmar (Chang et al. 2012), Thailand (Chang et al. 2012), Laos (Chang et al. 2012), Cambodia (Chang et al. 2012), Vietnam (Chang et al. 2012), the Philippines (Alston 1935a,b; Tagawa 1973; Tsai and Shieh 1994; Chang et al. 2012), Peninsular Malaysia (Wong 1982; Chang et al. 2012). In Indonesian archipelago, S. repanda occurred in Java (Alston 1935a; Tagawa 1973; Tsai and Shieh 1994; Chang et al. 2012), Sumatra (Chang et al. 2012), and the Lesser Sunda islands (Alston 1935a; Tagawa 1973; Tsai and Shieh 1994; Chang et al. (2012).

Furthermore, the model predicts the occurrence of climatically suitable habitat for $S$. involvens in highland areas in Sumatra and Papua islands, with no historical or current records to confirm or disconfirm this result. Likewise, several historical and recent studies confirmed the occurrence of this species in mainland SEA (e.g., Spring 1843; Tagawa and Iwatsuki 1967; Mark 2007; Boonkerd et al. 2008). In the maritime SEA the confirmed occurrence was in the Philippines (Tan 2013), while in Indonesia were Java island (Setyawan 2009; Setyawan et al. 2012), Lesser Sunda islands (Spring 1843), and Sumatra (Spring 1843). Meanwhile, there are large areas predicted as climatically suitable in lowland areas of Sulawesi, Borneo and Papua islands which are un-backed by occurrence data from both studies and documents resources. While, it will be impossible to calculate the precise commission error given that we do not have an absence data of these islands, we assume that those areas may just represent suitable but unoccupied habitat.

The predicted distribution of suitable habitat apparently will be significantly disturbed by future climate condition. Our models show a significantly negative trend of $S$. involvens and $S$. repanda distribution under the influence of accelerated global climate change. Under the lowest GHG emission projection (RCP 2.6), when radiative forcing reaches $3.1 \mathrm{~W} / \mathrm{m}^{2}$ before it returns to $2.6 \mathrm{~W} / \mathrm{m}^{2}$ by
2100 , there will be a rise in annual mean temperature up to $1.7^{\circ} \mathrm{C}$ in all areas of SEA region. Unlike the case of temperature, the changes in precipitation would not be the same in all SEA region areas. There will be both areas where the amount of precipitation shows a decreasing tendency (e.g., southern Indonesia, Thailand, Laos, and Myanmar) and where that shows an increasing tendency (Northern Philippines, Myanmar, and Laos), by the end of $21^{\text {st }}$ century (Figure 6) (IPCC 2014). This condition leads to $10 \%$ decrease of $S$. involvens suitable habitat, which occurs at a greater rate in areas where the precipitation predicted to decrease, than in areas which the precipitation predicted to increase (Figure 4, Figure 6). Likewise, under the worst scenario projection (RCP 8.5; radiative forcing $8.5 \mathrm{~W} / \mathrm{m}^{2}$ by 2100 ), the magnitude of temperature increase to about $3-5^{\circ} \mathrm{C}$ and annual precipitation will mostly increase at a great level of changes, with some exception areas where the precipitation is predicted to increase (Figure 6). Under this scenario, 27\% and 29\% climatically suitable habitat for $S$. involvens and $S$. repanda will be lost, respectively. Several studies have tried to explain the impact of these temperature and precipitation changes on the establishment epiphytic plants. Elis et al. (2005) and Ellis et al. (2009) reported a decreasing trend of the climatically suitable habitat in response to shifting rainfall patterns. Meanwhile, Hsu et al. (2012) and Ellis et al. (2014) reported that under suboptimal climate condition, there will be altitudinal shifting of epiphyte distribution by c. 300-400 m higher than current distribution which shows a high correlation with temperature-related factors in its distribution.

In this study, we extracted the altitudinal value of the predicted suitable habitat under RCP 2.6 and RCP 8.5 climate scenarios in the attempt to ensure whether there will also be altitudinal shifting or not (Figure 7). Across the periods of time, our models showed that both species are projected to marginally shifted to higher altitudes. Although the shifting is relatively small, the figure still represents the attempt of species to cope with the changes in temperature and precipitation variability. Increased temperature and occurrence of severe drought, as indicated by precipitation variability, should increase plant stress in some years (Kelly and Goulden 2008). Thus, expected to decrease the species' ability to survive in the drier, warmer, lower parts of its range (Allen and Breshears 1998; Lenoir et al. 2008a,b) and increase its competitive ability and tolerance in the wetter, cooler, upper parts of its range (Parmesan and Yohe 2003; Parmesan 2006). Despite there are several areas where climatically suitable habitat for both species are overlapped, there is still a gap in the majority of altitudinal distribution between both species' suitable habitats (Figure 7). Therefore, we may assume that there could be an altitudinal buffer related to local microclimate limiting the redistribution of species in response to the climate change. The habitat microclimate and micro-environment itself are not included in the climate data and therefore not modeled. 

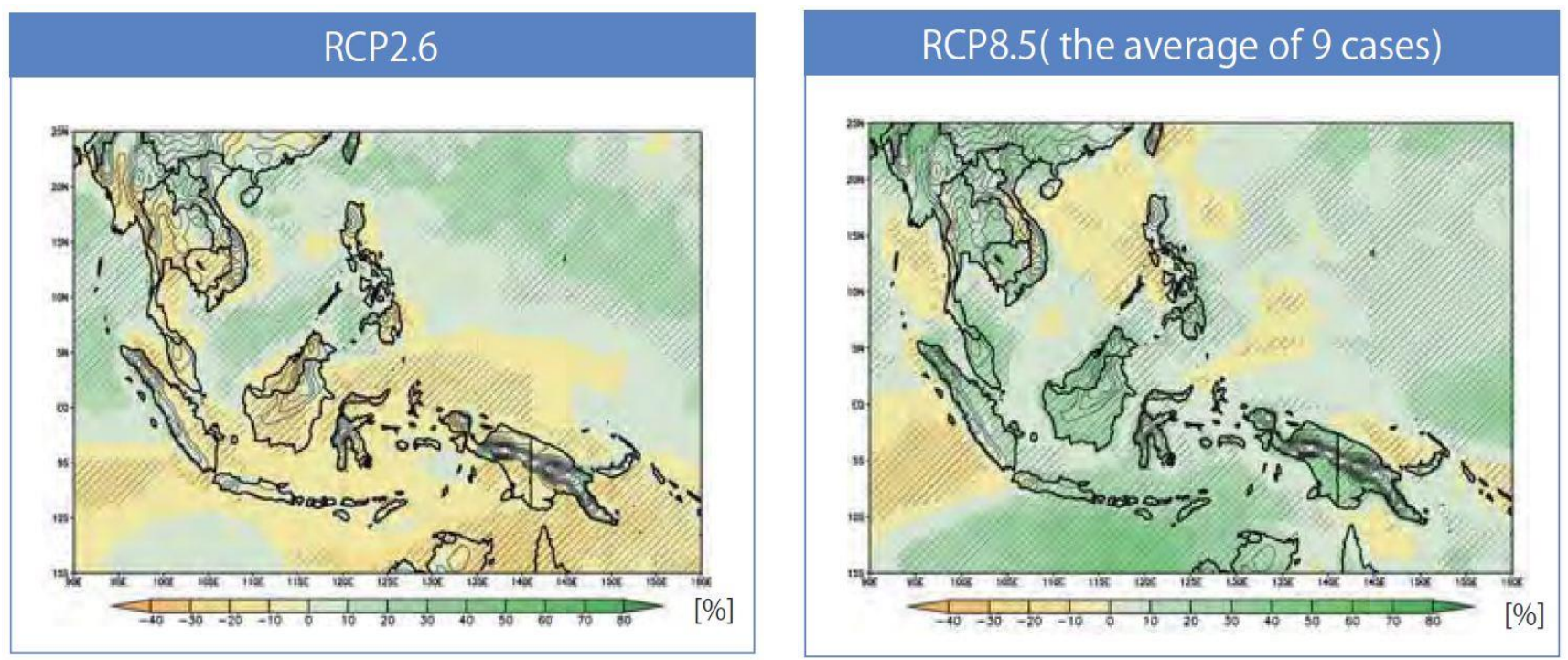

Figure 6. Changes (\%) in annual mean precipitation under 2.6 and 8.5 scenarios in Southeast Asia. Colors represent the difference in precipitation between present climate and future climate (2080-2100). (images are acquired from Data Integration and Analysis System (DIAS), Ministry of the Environment, Japan, 2014. Under open license agreement stated in the document and https://dias-dss.tkl.iis.utokyo.ac.jp)
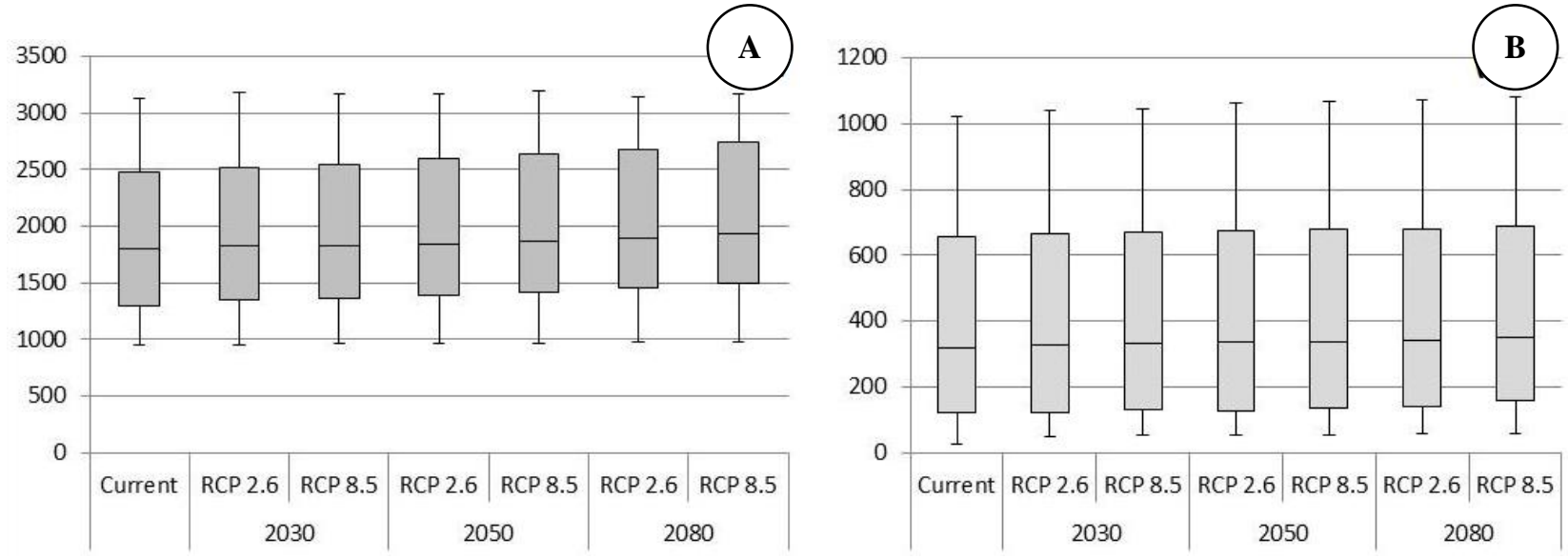

Figure 7. Box plot of median altitudes of (A) Selaginella involvens, (B) Selaginella repanda suitable habitat distribution under current and future climate scenarios. The plots present median, lower quartile, upper quartile, maximum and minimum observations. Altitude is measured in $\mathrm{m}$ asl. (meter above sea level)

The impact of multiple compounding factors acting simultaneously on species and its associated biota under anthropogenic actions and accelerated climate change would be very difficult to model, but the combined consequence is likely to be negative. There were several limitations in the availability of more detailed ecological and physiological data which prevent the build of more ideal models (Morin and Thriller 2009; Sinclair et al. 2010; Ellis 2011). Recent development of the new climate models and the refining of current climate models provide opportunity to build more precise and ideal models of future distribution trends of $S$. involvens and $S$. repanda. Future mapping and modeling process should incorporate potential land use land/land cover changes, more detailed ecological data, and accurately recorded presence and absence data to build the better assessment models. Despite these limitations, our study has established the baseline for assessing the impact of future climate change on $S$. involvens and $S$. repanda. While the quantitative results would be slightly different if using another niche and climate models, we believe that the presents resources of data will provide similar overall trend and projection 
results. Thus, it is concluded that the survival of $S$. involvens and $S$. repanda are, and will continue to be, strongly influenced by climate change, and that in most cases the outcome will be negative.

\section{REFERENCES}

Aguirre-Gutiérrez J, Carvalheiro LG, Polce C, van-Loon EE, et al. 2013. Fit-for-Purpose: Species Distribution Model Performance Depends on Evaluation Criteria - Dutch Hoverflies as a Case Study. PLoS One 8 (5): DOI: 10.1371/journal.pone.0063708.

Alice CH, Satasook S, Paul J, Bates, Bumrungsri S, Jones G. 2012. The projected effects of climatic and vegetation changes on the distribution and diversity of Southeast Asian bats. Glob Change Biol 18 (6): 1854-1865.

Allen CD, Breshears DD. 1998. Drought-induced shift of a forestwoodland ecotone: Rapid landscape response to climate variation. Proc Natl Acad Sci USA 95: 14839-14842.

Allouche O, Tsoar A, Kadmon R. 2006. Assessing the accuracy of species distribution models: prevalence, kappa and the true skill statistic (TSS). J Appl Ecol 43: 1223-1232.

Alston AHG. 1934. The genus Selaginella in the Malay Peninsula. Gard Bull Strait Settl 8: 41-62.

Alston AHG. 1935a. The Selaginella of the Malay Islands: I. Java and the Lesser Sunda Islands. Bull Jard Bot Buitenzorg 3 (13): 432-442.

Alston AHG. 1935b. The Philippines species of Selaginella. Philippines J Sci 58: 359-383.

Alston AHG. 1937. The Selaginella of the Malay Islands: II. Sumatra. Bull Jard Bot Buitenzorg 3 (14): 175-186.

Alston AHG. 1940. The Selaginella of the Malay Islands: III. Celebes and the Moluccas. Bull Jard Bot Buitenzorg 3 (16): 343-350.

Anderson RP, Raza A. 2010. The effect of the extent of the study region on GIS models of species geographic distributions and estimates of niche evolution: preliminary tests with montane rodents (Genus Nephelomys) in Venezuela. J Biogeogr 37: 1378-1393.

Bahn V, McGill BJ. 2013. Testing the predictive performance of distribution models. Oikos 122 (3): 321-331.

Bean WT, Stafford R, Brashares JS. 2012. The effects of small sample size and sample bias on threshold selection and accuracy assessmen of species distribution models. Ecography 35: 250-258.

Beaumont LJ, Pitman A, Perkins S, Zimmermann NE, Yoccoz NG, Thuiller W. 2011. Impacts of climate change on the world's most exceptional ecoregions. Proc Natl Acad Sci USA 108 (6): 2306-2311.

Beaumont LJ, Pitman AJ, Poulsen M, Hughes L. 2007. Where will species go? Incorporating new advances in climate modelling into projections of species distributions. Glob Ch Biol 13: 1368-1385.

Belgacem AO, Louhaichi M. 2013. The vulnerability of native rangeland plant species to global climate change in the West Asia and North African regions. Clim Ch 119: 451-463.

Belgacem OA, Salem BH, Bouaicha A, El-Mourid M. 2008. Communa rangeland rest in arid area, a tool for facing animal feed costs and drought mitigation: the case of Chenini Community, Southern Tunisia. J Biol Sci 8 (4): 822-825.

Bellard C, Bertelsmeier C, Leadley P, Thuiller W, Courchamp. 2012. Impacts of climate change on the future of biodiversity. Ecol Lett 15 (4): 365-383

Bonebrake TC, Mastrandrea MD. 2010. Tolerance adaptation and precipitation changes complicate latitudinal patterns of climate change impacts. Proc Natl Acad Sci USA 107 (28): 12581-12586.

Boonkerd T, Chantanaorrapint S, Khwaiphan W. 2008. Pteridophyte Diversity in the Tropical Lowland Rainforest of Khao Nan National Park, Nakhon Si Thammarat Province, Thailand. Nat Hist J Chulalongkorn Univ 8 (2): 83-97.

Boonkerd T, Ratchata P. 2002. Pteridophyte flora of Khun Korn waterfal forest park, Chiang Rai province, Thailand. Nat Hist Bull Siam Soc 50 (2): 195-210.

Botkin DB, Saxe H, Miguel B, et al. 2007. Forecasting the effects of global warming on biodiversity. Bioscience 57 (3): 227-238.

Brown JL. 2014, SDMtoolbox: a python-based GIS toolkit for landscape genetic, biogeographic, and species distribution model analyses. Methods Ecol Evol 5 (7): 1-7.
Burns K. 2007. Network properties of an epiphyte metacommunity. J Ecol 95: 1142-1151.

Carter TR, Jones RN, Lu X et al. 2007. New assessment methods and the characterization of future conditions. In: Parry ML, Canziani OF, Palutikof JP, van der Linden PJ, Hanson CE (eds) Climate change 2007: Impacts, adaptation and vulnerability. Contribution of Working Group II to the Fourth Assessment Report of the Intergovernmental Panel on Climate Change. Cambridge University Press, Cambridge.

Chang HM, Chiou WL, Wang JC. 2012. Flora of Taiwan, Selaginellaceae. Endemic Species Research Institute, Nantou, Taiwan.

Chen IC, Hill JK, Ohlemüller R, Roy DB, Thomas CD. 2011. Rapid range shifts of species associated with high levels of climate warming. Science 333 (6045): 1024-1026.

Clarke L, Edmonds J, Jacoby H, Pitcher H, Reilly J, Richels R. 2007. Scenarios of Greenhouse Gas Emissions and Atmospheric Concentrations. Sub-report 2.1A of Synthesis and Assessment Product 2.1 by the U.S. Climate Change Science Program and the Subcommittee on Global Change Research. Department of Energy, Office of Biological \& Environmental Research, Washington DC.

Collins WJ, Bellouin N, Doutriaux-Boucher M, Gedney N, Halloran P, et al. 2011. Development and evaluation of an Earth-System modelHadGEM2. Geosci Model Dev Discuss 4: 997-1062.

Cosico VB. 1972. Morphological studies on the genus Selaginella of the Philippines: I. Leaf epidermal elements, II. Shoot apical meristems, and III. Sporangial development. [Thesis]. University of the Philippines. Los Banos, the Philippines.

Dawson TP, Jackson ST, House JI, Prentice IC, Mace GM. 2011. Beyond predictions: biodiversity conservation in a changing climate. Sci 332 (6025): 53-58

Deb JC, Phinn S, Butt N, McAlpine CA. 2017. The impact of climate change on the distribution of two threatened Dipterocarp trees. Ecol Evol 7: 2238-2248.

Duan RY, Kong XQ, Huang MY, Fan WY, Wang ZG. 2014. The Predictive Performance and Stability of Six Species Distribution Models. PLoS ONE 9 (11). DOI: 10.1371/journal.pone.0112764.

Duan RY, Xiao-Quan K, Min-Yi H, Sara V, Xiang J. 2016. The potential effects of climate change on amphibian distribution, range fragmentation and turnover in China. Peer J 4: 165-174.

Dudik M, Schapire RE, Phillips SJ. 2005. Correcting sample selection bias in maximum entropy density estimation. App Advan Neural Inform Process Sys 18: 181-197.

Eaton S, Ellis CJ. 2012. Local experimental growth rates respond to macroclimate for the lichen epiphyte Lobaria pulmonaria. Plant Ecol Divers 5: 365-372.

Elith J, Graham CH, Anderson P, Dudik M, Ferrier S, et al. 2006. Novel methods improve prediction of species distributions from occurrence data. Ecography 29: 129-136.

Elith J, Kearney M, Phillips S. 2010. The art of modeling range-shifting species. Methods Ecology Evol 1: 330-342.

Elith J, Phillips SJ, Hastie T, Dudik M, Chee YE, Yates CJ. 2011. A statistical explanation of Maxent for ecologists. Divers Distrib 17: 4357.

Ellis CJ, Coppins BJ, Dawson TP. 2007. Predicted response of the lichen epiphyte Lecanora populicola to climate change scenarios in a cleanair region of Northern Britain. Biol Conserv 135 (2): 396-404.

Ellis CJ, Eaton S, Theodoropoulos M, Brian JC, Mark RD, Seaward, Janet S. 2014. Response of epiphytic lichens to 21st Century climate change and tree disease scenarios. Bio Conserv 180: 153-164.

Ellis CJ, Yahr C, Coppins BJ. 2009. Local extent of old-growth woodland modifies epiphyte response to climate change. J Biogeogr 36: 302 313.

Ellis CJ. 2011. Predicting the biodiversity response to climate change: challenges and advances. Syst Biodiv 9: 307-317.

Engler R, Guisan A. 2009. MigClim: Predicting plant distribution and dispersal in a changing climate. Divers Distrib 15 (4): 590-601.

Everhart SE, Ely JS, Keller HW. 2009. Evaluation of tree canopy epiphytes and bark characteristics associated with the presence of corticolous myxomycetes. Botany 87: 509-517.

FAO. 2000. FRA 2000. Global Ecological Zoning for the Global Forest Resources Assessment 2000. FRA Working Paper 56. FAO, Rome.

FAO. 2012. FRA 2015. Global Ecological Zones for FAO Forest Reporting: 2010 Update. FRA Working Paper 179. FAO, Rome.

Fick SE, Hijmans RJ. 2017. Worldclim 2: New 1-km spatial resolution climate surfaces for global land areas. Int J Climat SEA 6: 817-823.

Fischer D, Thomas SM, Niemitz F, Reineking B, Beierkuhnlein C. 2011. Projection of climatic suitability for Aedes albopictus Skuse 
(Culicidae) in Europe under climate change conditions, Glob Planetary Ch 78 (1-2): 54-64.

Fitzpatrick MC, Gove AD, Sanders NJ, Dunn RR. 2008. Climate change, plant migration, and range collapse in a global biodiversity hotspot: the Banksia (Proteaceae) of Western Australia. Glob Ch Biol 14: 1337-1352.

Flores-Palacios A, García-Franco JG. 2006. The relationship between tree size and epiphyte species richness: testing four different hypotheses. J Biogeogr 33: 323-330.

Fourcade Y, Engler JO, Besnard AG, Rödder D, Secondi J. 2013. Confronting expert-based and modelled distributions for species with uncertain conservation status: a case study from the Corncrake (Crex crex). Biol Conserv 167: 161-171.

Fourcade Y, Engler JO, Rodder D, Secondi J. 2014. Mapping species distributions with MAXENT using a geographically biased sample of presence data: A performance assessment of methods for correcting sampling bias. PLoS ONE 9(5): e97122. DOI: 10.1371/journal.pone.0097122.

Franklin J. 2010. Mapping Species Distributions. Cambridge University Press. Cambridge.

GAA. 2017. Global Administrative Areas. www.gadm.org

Garavito TN, Golicher D, Oldfield S. 2015. The relative impact of climate change on the extinction risk of tree species in the Montane Tropical Andes. PLoS ONE10(7): $\quad$ e131388. DOI: 10.1371/journal.pone. 0131388

Gavin DG, Hu FS. 2006. Spatial variation of climatic and non-climatic controls on species distribution: the range limit of Tsuga heterophylla. J Biogeogr 33: 1384-1396.

GBIF. 2017. Global Biodiversity Information Facility. www.gbif.org

Gilman SE, Urban MC, Tewksbury J, Gilchrist GW, Holt RD. 2010. A framework for community interactions under climate change. Trends Ecol Evol 25 (6): 325-331.

Google Earth Pro. 2017. Download Google Earth Pro for PC, Mac, or Linux. https://www.google.com/earth/download/gep/agree.html

Guisan A, Thuiller W. 2005. Predicting species distribution: offering more than simple habitat models. Ecol Lett 8: 993-1009.

Guralnick RP, Wieczorek J, Beaman R, Hijmans RJ, the BioGeomancer Working Group. 2006. BioGeomancer: Automated Georeferencing to Map the World's Biodiversity Data. PLoS Biol 4(11): e381. DOI: 10.1371/journal.pbio.0040381.

Hansen MC, Potapov PV, Moore R, Hancher M, Turubanova S, Tyukavina A, Loveland T. 2013. High-resolution global maps of 21stcentury forest cover change. Science 342: 850-853.

Hernandez PA, Franke I, Herzog SK, Pacheco V, Paniagua L, Quintana HL, Soto A, Swenson JJ, Tovar C, Valqui TH, Vargas J, Young BE. 2008. Predicting species distributions in poorly-studied landscapes. Biodiv and Conserv 17: 1353-1366.

Hijmans RJ, Cameron SE, Parra JI, Jones PG, Jarvis A. 2005. Very high resolution interpolated global surfaces for global land areas. Intl $\mathrm{J}$ Climatol 25: 1965-1978.

Hijmans RJ. 2012. Cross-validation of species distribution models: removing spatial sorting bias and calibration with a null model. Ecology 93: 679-688.

Hilbish TJ, Brannock PM, Jones KR, Smith AB, Bullock BN, Wethey DS 2010. Historical changes in the distributions of invasive and endemic marine invertebrates are contrary to global warming predictions: the effects of decadal climate oscillations. J Biogeogr 37: 423-431.

Hill MO, Preston CD. 2015. Disappearance of boreal plants in southern Britain: habitat loss or climate change?. Biol J Linn Soc 115 (3): 598610.

Hsu RCC, Tamis WLM, Raes N, Wolf GR, de Snoo JHD, Oostermeijer $\mathrm{G}$, et al. 2012. Simulating climate change impacts on forests and associated vascular epiphytes in a subtropical island of East Asia. Divers Distrib 18: 334-347.

IPCC. 2014. In: Solomon S, Qin D, Manning M, Chen Z, Marquis M, Averyt KB, Tignor M, Miller HL (eds) Climate change 2014: The physical science basis. Contribution of Working Group I to the Fifth Assessment Report of the Intergovernmental Panel on Climate Change. Cambridge University Press, Cambridge, United Kingdom.

Jiménez-Valverde A. 2012. Insights into the area under the receiver operating characteristic curve (AUC) as a discrimination measure in species distribution modelling. Global Ecol Biogeogr 21 (4): 498-507.

Jin Z, Matsumoto Y, Tange T, liyama K. 2007. Structural characteristics of lignin in primitive pteridophytes: Selaginella Species. J Wood Sci 53: $412-418$.
Jochum GM, Mudge KW, Thomas RB. 2007. Elevated temperatures increase leaf senescence and root secondary metabolite concentrations in the understory herb Panax quinquefolius (Araliaceae). Am J Bot 94: 819-826.

Johnston KM, Freund KA, Schmitz OJ. 2012. Projected range shifting by montane mammals under climate change: implications for Cascadias National Parks. Ecosphere 3 (11): 97-116.

Kelly AE, Goulden ML. 2008. Rapid shifts in plant distribution with recent climate change. Proc Natl Acad Sci USA 105 (33): 1182311826.

Koster N, Nieder J, Barthlott W. 2014. Effect of host tree traits on epiphyte diversity in natural and anthropogenic habitats in Ecuador. Biotropica 43: 685-694.

Kou X, Li Q, Liu S. 2011. Quantifying species' range shifts in relation to climate change: a case study of Abies spp. in China. PLoS ONE 6 (8): e23115. DOI: 10.1371/journal.pone.0023115.

Kozak KH, Graham CH, Wiens JJ. 2008. Integrating GIS-based environmental data into evolutionary biology. Trends Ecol Evol 23: 141-148.

Lasalita-Zapico F, Catherine HA, Benigno L, Norjean B. 2011. Phenotypic Variations of Extant Ferns in Mt. Hamiguitan Range, Mindanao Island, Philippines. World Appl Sci J 12 (7): 979-987.

Lenoir J, Gegout JC, Marquet PA, Ruffray P, Brisse H. 2008a.A significant upward shift in plant species optimum elevation during the 20th century. Science 320. DOI: 10.1126/science.1156831.

Lenoir J, Gegout JC, Marquet PA, Ruffray P, Brisse H. 2008b. A significant upward shift in plant species optimum elevation Southeast Asia. Geosci Front 6: 817-823.

Li W, Guo Q. 2013. How to assess the prediction accuracy of species presence-absence models without absence data? Ecography 36 (7): 788-799.

Li ZJ, Tan BC. 2005. A review of the species diversity of Selaginella in Fujian Province of China. Acta Phytotaxonomica Sinica 43 (1): 50-59

Liu C, Newell G, White M. 2016. On the selection of thresholds for predicting species occurrence with presence-only data. Ecol Evol 6 (1): 337-348.

Liu C, White M, Newell G. 2013. Selecting thresholds for the prediction of species occurrence with presence-only data. J Biogeogr 40: 778789.

Lobo JM, Jiménez-Valverde A, Real R. 2008. AUC: a misleading measure of the performance of predictive distribution models. Glob Ecol Biogeogr 17 (2): 145-151.

Loo YY, Billa L, Singh A. 2015. Effect of climate change on seasonal monsoon in Asia and its impact on the variability of monsoon rainfall in

Mandar R, Trivedi W, Pamela M, Berry, Michael D, Morecroft Z, Terence PD. 2008. Spatial scale affects bioclimate model projections of climate change impacts on mountain plants. Glob Ch Biol 14: 10891103

Marjorie D, Delos A, Inocencio EB. 2015. Diversity and Distribution of Pteridophytes along the Altitudinal Gradient of the Northeastern Slope of a Secondary Forest in Mt. Makiling, Philippines. Intl J Ecol Conserv 25. DOI: 10.7718/ijec.v16i1.1015.

McMahon SM, Harrison SP, Armbruster WS, Bartlein PJ, Beale CM, Edwards ME, Kattge J, Midgley G, Morin X, Prentice IC. 2011. Improving assessment and modelling of climate change impacts on global terrestrial biodiversity. Trends Ecol Evol 26 (5): 249-259.

Merow C, Matthew J, Smith, John A, Silander Jr. 2013. A practical guide to Maxent for modeling species' distributions: what it does, and why inputs and settings matter. Ecography 36: 1058-1069.

Minteer BA, Collins JP. 2010. Move it or lose it? The ecological ethics of relocating species under climate change. Ecol Appl 20: 1801-1804.

Montgomery R, Roloff GJ, Hoef M. 2011. Implications of ignoring telemetry error on inference in wildlife resource use models. J Wildl Manag 75: 702-708.

Morin X, Thuiller W. 2009. Comparing niche- and process-based models to reduce prediction uncertainty in species range shifts under climate change. Ecol Lett 90: 1301-1313.

Morris RJ. 2010. Anthropogenic impacts on tropical forest biodiversity: A network structure and ecosystem functioning perspective. Biol Sci 365: 3709-3718.

Morueta-Holme N, Engemann K, Sandoval-Acuña P, Jonas JD, Segnitz RM, Svenning JC. 2015. Strong upslope shifts in Chimborazo's vegetation over two centuries since Humboldt. Proc Natl Acad Sci USA 112 (41): 12741-12745. DOI: 10.1073/pnas. 1509938112 
Moss RH, Edmonds JA, Hibbard KA, Manning MR, Rose SK, et al. 2010 The next generation of scenarios for climate change research and assessment. Nature 463: 747-756.

Nadkarni NM. 2010. Potential effects of global climate change on epiphytes in a tropical montane cloud forest: an experimental study from Monteverde, Costa Rica. In: Bruijnzeel LA, (ed) Tropica Montane Cloud Forests: science for conservation and management Cambridge, UK: Cambridge University Press. Cambridge, UK.

Nenzén HK, Araújo M. 2011. Choice of threshold alters projections of species range shifts under climate change. Ecol Model 222: 33463354.

Newman M, Ketphanh S, Svengsuksa B, Thomas P, Sengdala P, Lamxay V, Armstrong K. 2007. A Checklist of the Vascular Plants of Lao PDR. Royal Botanic Garden Edinburg, Edinburgh.

Nguyen AH, DT Le, Mai MTN. 2012. Investigating diversity of botanic resource at Linh Thong commune, Dinh Hoa district, Thai Nguyen province. Tap Chi Sinh Hoc (Viet Acad Sci Tech) 34 (2). DOI $10.15625 / 0866-160 / \mathrm{v} 34 \mathrm{n} 4.2682$.

NIC. 2009. The Impact of Climate Change to 2030 Commissioned Research and Conference Reports. National Intelligence Council, Washington DC.

Norris D. 2014. Model thresholds are more important than presence location type: Understanding the distribution of lowland tapir (Tapirus terrestris) in a continuous Atlantic forest of southeast Brazil Trop Conserv Sci 7 (3): 529-547.

Parmesan C, Yohe G. 2003. A globally coherent fingerprint of climate change impacts across natural systems. Nature 421: 37-42

Parmesan C. 2006. Ecological and evolutionary responses to recent climate change. Ann Rev Ecol Evol Syst 37: 637-669.

Parris BS, Kiew R, Chung RCK, Saw LG, Soepadmo E. 2010. Flora of Peninsular Malaysia, Series I: Ferns and Lycophytes. Forest Research Institute Malaysia (FRIM), Malaysia.

Pearson RG, Dawson TP. 2003. Predicting the impacts of climate change on the distribution of species: are bioclimatic envelope models useful? Glob Ecol Biogeogr 12: 361-371.

Pearson RG, Raxworthy C, Nakamura M, Peterson AT. 2007. Predicting species distributions from small numbers of occurrence records: a test case using cryptic geckos in Madagascar. J Biogeogr 34: 102-117.

Pereira HM, Leadley PW, Proença V, Alkemade R, et al. 2010. Scenarios for global biodiversity in the 21 st century. Science 330 (6010): 14961501.

Phillips SJ, Anderson RP, Dudík M, Schapire RE, Blair ME. 2017 Opening the black box: an open-source release of Maxent. Ecography 40 (7): 887-893.

Phillips SJ, Anderson RP, Schapire RE. 2006. Maximum entropy modeling of species geographic distributions. Ecol Model 190: 231259.

Phillips SJ, Dudık M, Elith J, Graham CH, Lehmann A, et al. 2009. Sample selection bias and presence-only distribution models: implications for background and pseudo-absence data. Ecol Appl 19: 181-197.

Phillips SJ, Dudík M, Schapire RE. 2017. Maxent software for modeling species niches and distributions (Version 3.4.1) http://biodiversityinformatics.amnh.org/open_source/maxent/.

Phillips SJ, Dudík M, Schapire RE. 2017b. Maxent software for modeling species niches and distributions (Version 3.4.1). Available from url: http: //biodiversityinformatics.amnh.org/open_source/Maxent/. Accessed on 2017-7-31.

Phillips SJ, Dudik M. 2008. Modeling of species distributions with Maxent: new extensions and a comprehensive evaluation. Ecography 31: 161-175.

Phillips SJ, Elith J. 2013. On estimating probability of presence from use-availability or presence-background data. Ecology 94:1409-1419.

QGIS. 2017. QuantumGIS software ver. 2.18.11. QGIS A Free and Open Source Geographic Information System. www.qgis.org/en/site/

Radosavljevic A, Robert P. Anderson. 2013. Making better MAXENT models of species distributions: complexity, overfitting and evaluation. J. Biogeogr 41: 629-643.

Ramirez J, Jarvis A. 2008. High resolution statistically downscaled future climate surfaces. International Center for Tropical Agriculture (CIAT); CGIAR Research Program on Climate Change, Agriculture and Food Security (CCAFS) Cali, Colombia. www.ccafsclimate.org/statistical_downscaling_delta [1 August 2017].

Ramirez-Villegas J, Challinor AJ, Thornton PK, Jarvis A. 2013. Implications of regional improvement in global climate models for agricultural impact research. Environ Res Lett 8: 1-12.
Randin CF, Engler R, Normand S, et al. 2008. Climate change and plant distribution: local models predict high-elevation persistence. Glob $\mathrm{Ch}$ Biol 15 (6): 1557-1569.

Riahi K, Rao S. Krey V. et al. 2011. RCP 8.5-A scenario of comparatively high greenhouse gas emissions. Clim Ch 109 (33): 364-379.

Rodder D, Schmidtlein S, Schick S, Lotters S. 2010. Climate Envelope Models in systematics and evolutionary research: theory and practice. In: Hodkinson T, Jones M, Parnell J, Waldren S (eds.) Systematics and Climate Change. Cambridge University Press, Cambridge, UK.

Rondinini C, Wilson KA, Boitani L, Grantham H, Possingham HP. 2006. Tradeoffs of different types of species occurrence data for use in systematic conservation planning. Ecol Lett 9 (10): 1136-1145.

Rosell JA, Gleason S, Méndez-Alonzo R, Chang Y, Westoby M. 2014. Bark functional ecology: evidence for tradeoffs, functional coordination, and environment producing bark diversity. New Phytol 201 (2): 486-497.

Salamin N, Wüest RO, Lavergne S, Thuiller W, Pearman PB. 2010. Assessing rapid evolution in a changing environment. Trends Ecol Evol. 25 (12): 692-698

Sayago R, Lopezaraiza-Mikel M, Quesada M, Álvarez-Añorve MY, Cascante-Marín A, Bastida JM. 2013. Evaluating factors that predict the structure of a commensalistic epiphyte-phorophyte network. Proc Biol Sci 280. DOI: 10.1098/rspb.2012.2821.

Schewe J, Levermann A. 2012. A statistically predictive model for future monsoon failure in India. Environ Res Lett 7: 23-34.

Schneider R, Boutin S, Stelfox J, Wasel S. 2007. Scenarios are plausible stories about the future, not forecasts. Ecol Soc 12 (1): 1-14.

Setyawan AD, Sugiyarto, Susilowati A, Widodo. 2015a. Diversity and distribution of Selaginella in the Province of Yogyakarta Special Region. Pros Sem Nas Masy Biodiv Indon 1: 986-991.

Setyawan AD, Sugiyarto, Susilowati A, Widodo. 2015b. Diversity of Selaginella in the karstic region of Sewu Mountains, Southern Java. Pros Sem Nas Masy Biodiv Indon 1: 1318-1323.

Setyawan AD, Sugiyarto, Widiastuti A. 2012. Species diversity of Selaginella in Mount Merapi National Park, the central part of Java. Proc Soc Indon Biodiv Intl Conf 1: 102-106.

Setyawan AD, Sugiyarto, Widiastuti A. 2015c. Species diversity of Selaginella in the Dieng Plateau, Central Java. Pros Sem Nas Masy Biodiv Indon 1: 980-985.

Setyawan AD, Sugiyarto. 2015. Diversity of Selaginella in the Bromo Tengger Semeru National Park, East Java. Pros Sem Nas Masy Biodiv Indon 1: 1312-1317.

Setyawan AD, Supriatna J, Darnaedi D, Rokhmatuloh, Sutarno, Sugiyarto. 2016. Diversity of Selaginella across altitudinal gradient of the tropical region. Biodiversitas 17: 384-400

Setyawan AD, Sutarno, Sugiyarto. 2013. Species diversity of Selaginella in Mount Lawu, Java, Indonesia. Biodiversitas 14: 1-9.

Setyawan AD. 2009. Traditionally utilization of Selaginella; field research and literature review. Nusantara Biosci 1 (3): 146-158.

Setyawan AD. 2012. Altitudinal distribution of Selaginella in the southern part of Central Java, Indonesia. Proc Soc Indon Biodiv Intl Conf 1: 153-157.

Shrestha UB, Bawa KS. 2014. Impact of climate change on potential distribution of Chinese caterpillar fungus (Ophiocordyceps sinensis) in Nepal Himalaya. PLoS ONE 9 (9): e106405. DOI: 10.1371/journal.pone.0106405

Sinclair SJ, White MD, Newell GR. 2010. How useful are species distribution models for managing biodiversity under future climates? Ecol Soc 15: 8-16.

Spring AF. 1843. Enumeratio Lycopodinearum. Bull Acad Roy Sci Bruxelles 10 (6): 135-146

Stolar J, Nielsen SE. 2015. Accounting for spatially biased sampling effort in presence-only species distribution modeling. Divers Distrib 21 (5): 595-608.

Syfert MM, Smith MJ, Coomes DA. 2013. The effects of sampling bias and model complexity on the predictive performance of Maxent species distribution models. PLoS ONE 8 (2): e55158. DOI: 10.1371/journal.pone.0055158

Tabor K, Williams JW. 2010. Globally downscaled climate projections for assessing the conservation impacts of climate change. Ecol Appl 20 (2): 554-565.

Tagawa M, Iwatsuki K. 1967. Enumeration of Thai Pteridophytes Collected during 1965-66. Tokyo Univ Press, Tokyo.

Tagawa M. 1963. The Selaginella of the Ryukyu Islands. Sci Rep Tohoku Univ Ser IV (Biol) 29: 300-315 
Tagawa M. 1973. The Selaginella of Taiwan. Acta Phytotax Geobot 27 (4 6): $170-180$

Tan BC. 2013. The Selaginella Flora, A Good Indicator of the Philippine Pleistocene Island Groups. Phillip J Sci 142: 211-213.

Thuiller W, Albert C, Araujo MB, Berry PM, Cabeza M, et al. 2008 Predicting global change impacts on plant species' distributions: Future challenges. Pers Plant Ecol Evol Sys 9: 137-152.

Tsai JL, Shieh WC. 1994. Selaginellaceae. In: Huang TC (ed) Flora of Taiwan. Vol. 1. 2nd ed. Department of Botany, National Taiwan University, Taipei

USDA. 2002. National Genetic Resources Program. Germplasm Resources Information Network- (GRIN) National Germplasm Resources Laboratory, United States Department of Agriculture, Beltsville, Maryland. http: //www.ars-grin.gov/cgi-bin/npgs/html/ taxon.pl?33581 [11 August 2017]

Van Vuuren D, den Elzen M, Lucas P, Eickhout B, Strengers B, et al 2007. Stabilizing greenhouse gas concentrations at low levels: an assessment of reduction strategies and costs. Clim Ch 81: 119-159.

Van der Wall J, Shoo LP, Graham C, Williams SE. 2009. Selecting pseudo-absence data for presence-only distribution modeling: how far should you stray from what you know?. Ecol Model 220: 589-594.

Van Gils H, Conti F, Ciaschetti G, Westinga E. 2012. Fine resolution distribution modelling of endemics in Majella National Park, Central Italy. Plant Biosys 146 (1): 276-287

Van Gils H, Westinga E, Carafa M, Antonucci A, Ciaschetti G. 2014 Where the bears roam in Majella National Park, Italy. J Nat Conserv 22 (1): 23-34

Walther GR, Post E, Convey P, Menzel A, Parmesan C, Beebee T J, Bairlein F. 2002. Ecological responses to recent climate change. Nature 416: 389-395.
Wilson MC, Chen X, Corlett RT, Didham RK, Ding P, Holt RD, Jiang L. 2016. Habitat fragmentation and biodiversity conservation: Key findings and future challenges. Landsc Ecol 31: 219-227.

Winter WP, Jansen PCM. 2003. Selaginella Pal. Beauv. In: de Winter WP, Amoroso VB (eds). Plant resources of South-East Asia 15 (2) Cryptogams: ferns and fern allies. Backhuys, Leiden.

Wong KM. 1982. Critical observations on Peninsular Malaysian Selaginella. Gard Bull Sing 35 (2): 107-135

Wong KM. 2010. Selaginellaceae. In Parris BS, Kiew R, Chung RKC, Saw LG, Soepadmo E (eds) Flora of Peninsular4 Malaysia Series 1. Ferns and Lycophytes. Malayan Forest Records No. 48. FRIM Kepong, Selangor.

WorldClim. 2017. WorldClim - Global Climate Data. www.worldclim.org Youguang Y, Tan BC. 2013. The non-functional stomata on the leaf margin of Selaginella. Philipp J Sci 142: 245-248.

Zhang L, Nurvianto S, Harrison R. 2010. Factors affecting the distribution and abundance of Asplenium nidus L. in a tropical lowland rain forest in Peninsular Malaysia. Biotropica 42: 464-469.

Zhang XC, Nooteboom HP, Kato M. 2013. Selaginellaceae. In: Wu ZY, Raven PH, Hong DY (eds.). Flora of China, Vol. 2-3 (Pteridophytes). Science Press, Beijing \& Missouri Botanical Garden Press, St. Louis.

Zhou XM, Carl JR, Zhang L, He ZR, et al. 2015. A large-scale phylogeny of the lycophyte genus Selaginella (Selaginellaceae: Lycopodiopsida) based on plastid and nuclear loci. Cladistics 32 (4): 1-30

Zhou XM, Zhang LM. 2015. A classification of Selaginella (Selaginellaceae) based on molecular (chloroplast and nuclear), macromorphological, and spore features. Taxon 64 (6): 1117-1140.

Zotz G. 2007. Johansson revisited: the spatial structure of epiphyte assemblages. J Veget Sci 18 (1): 123-130. 